\title{
More foreign research students stay in US to cash in on boom
}

[WASHINGTON] Foreign research students who receive their doctorates in the United States are more likely than ever before to stay, taking advantage of the booming US economy to land postdoctoral fellowships or plum jobs in industry, according to figures collated by the National Science Foundation (NSF).

A survey has revealed that the number of students from Europe, Asia, Canada and Mexico obtaining PhDs in the United States rose sharply from 2,400 in 1985 to more than 8,000 in 1996 , the last year for which complete data were available. But the number of these who say that they "plan to stay" in the United States grew even more rapidly, rising from 50 per cent to 72 per cent of the total (see graph).

The number who say they have "firm plans to stay", meaning that they had received a firm job offer on receiving their degree, also reached a new high of 46 per cent in 1996. The NSF says that the response to this question is a good indicator of how many of the students will remain in the United States.

Students from China - by far the largest group, now accounting for more than onethird of the total - are the keenest and most likely to stay in the United States. Since Congress passed the Chinese Student Protection Act in 1992, granting most of them permanent residency status, the number saying that they hoped to stay has exceeded 90 per cent. By 1996, the number with firm plans to stay had reached 57 per cent.

Over the entire period surveyed, the students next most likely to stay were those from India, of whom 79 per cent plan to remain. Among students from European countries, those from the United Kingdom were by far the keenest to stay, with almost 70 per cent planning to do so. Of the other countries that send a large number of graduate students to the United States, about half of the students from Canada, Germany and Greece plan to remain, as do fewer than half of those from Taiwan and South Korea.

More than half of the British postgraduate students had received a firm job offer more than any other nation except India and 8 per cent had an offer to teach at a US university, almost twice the success rate of students from any other country in the study.

Students in the life sciences are the most likely of all to stay in the United States, with more than half reporting firm plans to stay, almost all of them planning to continue with postdoctoral study. Fewer of those studying the physical sciences, engineering and computer science plan to, and many of those who do will move directly into jobs in industry.

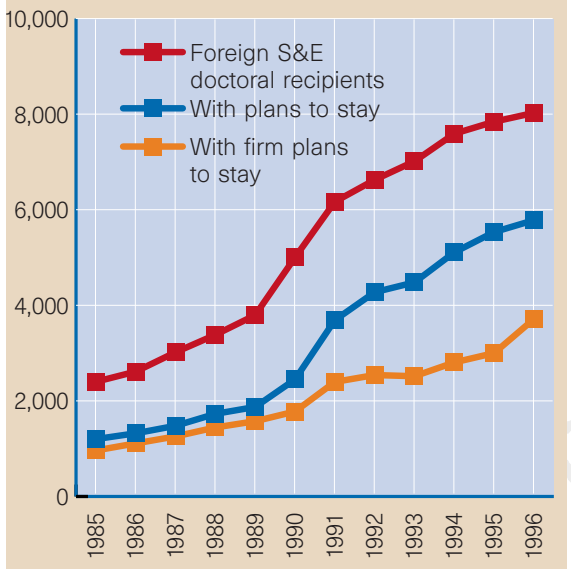

Staying Stateside: rising numbers of foreign science and engineering students hope to remain.

The study, which was published last month, excluded the smaller number of students who come to the United States from South America, Africa and the Middle East. The NSF says that the increase in research students choosing to remain in the United States is largely attributable to the sharp increase in the number of students from China and their tendency to stay after graduation.

"Although the increase in the 'stay rate' of Chinese students is largely responsible for the jump in the overall rate of those planning to stay, students from other countries are also contributing to the growing number of those who plan to say," says the report. "Undoubtedly the increase is a reflection of rising employment opportunities."

NSF officials believe that the underlying upward trend has continued since the last data were collected in 1996. "It looks like a pretty strong trend and I doubt that it will change," says Jennifer Bond, director of the NSF Science and Engineering Indicators Program.

Bond says that the strong US economy, combined with economic problems in Asia, will continue to encourage graduating research students to stay in the United States. But she points out that acute economic problems in some countries may mean that they send fewer students to the United States for postgraduate education.

In the mid-1990s, concern about unemployment among those with $\mathrm{PhDs}$ led to complaints from young US scientists about the number of foreign students being encouraged to study at US universities. But these complaints have been muted during the recent economic expansion, which has seen unemployment in the United States fall to the lowest rate for 30 years. Colin Macilwain

\section{UN stands up for East German scientists}

[MUNICH] The United Nations Committee on Economic, Social and Cultural Rights in Geneva last week noted "with alarm" the small number of scientists from the former German Democratic Republic (GDR) who have been re-employed after German unification.

The issue had been brought to the attention of the committee by human rights organizations and trade unions in Germany. The committee was unconvinced by the official German denial that discrimination against state officials and others associated with the former communist regime had ever taken place. The committee has called on the German government to provide compensation, employment or pensions "as an act of national reconciliation".

But German officials challenge the committee's conclusion that the scientists have been discriminated against politically. They argue that its statement claiming that most of those affected "may have been dismissed from their positions for political rather than for professional or economic reasons" is misleading.
Marion Bimmler, for example, head of the staff council at the Max Delbrück Centre for Molecular Medicine in Berlin, argues that "not more than 3 per cent" have been dismissed for political reasons, such as collaboration with the Stasi, the GDR's security service.

Nevertheless, only an estimated 15 per cent of the 24,000 scientists employed by the GDR's Academy of Sciences found permanent academic posts after the academy was dissolved in 1990. Each had to reapply for jobs in the new research institutes established along western lines, and many were unsuccessful in competition with candidates from west Germany and abroad (see Nature 370, 240; 1994).

Government-financed support programmes rescued some from immediate unemployment, but these finished in 1996.

Bimmler hopes that the government will provide more money to re-employ the scientists. She says that a new reintegration programme "would be much more helpful than sending competent people home with a pension".
Quirin Schiermeier 